\title{
INTERAKSI ANTARA MIKROBIOTA USUS DAN SISTEM KEKEBALAN TUBUH MANUSIA
}

\author{
Fitri Elizabrth Br Hasibuan ${ }^{1)}$ dan Beivy Jonathan Kolondam ${ }^{1)}$ \\ 1) Program Studi Biologi, FMIPA Universitas Sam Ratulangi Manado 95115 \\ E-mail: fitrielizabeth19@gmail.com; beivy.kolondam@unsrat.ac.id
}

\begin{abstract}
ABSTRAK
Sejumlah besar mikrobiota yang menghuni sistem pencernaan manusia memiliki peran penting dengan sistem kekebalan tubuh. Mikrobiota ini melaksanakan fungsi penting untuk fisiologi inang. Dalam tubuh manusia terdapat sekitar 10-100 triliun mikrobiota. Jumlah mikrobioma pada manusia paling banyak terdapat di usus, yaitu sekitar 100 triliun sel-sel mikrobiota yang terdiri dari 1.000 spesies berbeda. Mikrobiota adalah seluruh mikroba yang hidup di tubuh manusia yang terdiri dari bakteri, archae, virus, dan jamur yang pada umumnya hidup di setiap bagian tubuh manusia seperi kulit, vagina, hidung dan mulut. Bakteri pada mikrobioma manusia memiliki peran pada imunitas, nutrisi, dan perkembangan manusia. Di sini ditinjau tentang interaksi antara koloni mikroba dan sistem kekebalan tubuh dan implikasi dari temuan ini bagi kesehatan manusia.
\end{abstract}

Kata-kata kunci: mikrobiota usus, sistem kekebalan tubuh, interaksi, bakteria.

\section{INTERACTION BETWEEN GUT MICROBIOTA AND THE HUMAN IMMUNE SYSTEM}

\begin{abstract}
Most of the gut microbiota has important role in human immune system. These microbiota conducts important function for host physiology. The microbiota in the human body can range around 10 to 100 billion in number which contained 1,000 different species. Microbiota are the whole microbes living in human body such as bacteria, archaea, virus, and fungi, located on the skin or inside the vagina, nose and mouth. Bacteria in human microbiome has important roles in nutrition, immunity, and human development. This article discussed about interaction of microbes and immune system along with the implication of the interaction for human health.
\end{abstract}

Keywords: Gut microbiota, immune system, interaction, bacteria

\section{PENDAHULUAN}

Sistem gastrointestinal manusia adalah rumah dari sebagian besar mikroba seperti mikrobiota usus. Usus manusia memiliki sekitar 100 triliun sel-sel mikrobiota yang terdiri dari 1.000 spesies yang berbeda. Mikrobiota merupakan suatu kumpulan yang kompleks dari bakteri, archae, virus, dan jamur yang pada umumnya hidup di setiap bagian tubuh manusia seperi kulit, vagina, hidung dan mulut. Mikrobioma yang berasosiasi dengan manusia disebut mikrobiota, namun penggunaan kata "mikrobioma" dan "mikrobiota" sering digunakan bersamaan. Jumlah mikrobioma pada manusia paling banyak terdapat di usus (Dietert, 2015). Bakteri pada mikrobioma manusia memiliki peran pada imunitas, nutrisi, dan perkembangan manusia. Hasil penelitian mengatakan, microbioma atau mikrobiota (kumpulan bakteri) pada setiap orang berbeda sebagai akibat dari efek diet, gaya hidup, dan sumber bakteri di masa kecil (Prakash et al.,2011).

Mikrobioma berperan pada pengaturan proses biologis dan fisiologis tubuh. Adanya disfungsi sistem imun dan kesalahan regulasi inflamasi merupakan penyebab non-communicable disease and conditions (NCDs). Selain itu, gangguan pada mikrobioma dapat meningkatkan risiko infeksi (Dietert, 2015). Dalam saluran gastrointestinal juga ditemukan sejumlah besar mikroorganisme (mikroflora) yang dalam keadaan eubiosis (status seimbang antar populasi bakteri di dalam saluran 
gastrointestinal) mampu menjalankan berbagai fungsi penting yang bermuara pada menjaga kesehatan tubuh secara keseluruhan. Dalam kondisi dysbiosis (kondisi ketidakseimbangan antar populasi mikroflora dalam saluran gastrointestinal, kondisi disfungsi mikroflora gastrointestinal), mikroflora tersebut dapat menyebabkan munculnya berbagai gangguan kesehatan (Rolfe, 2000). Ini berarti, agar tetap sehat maka keseimbangan populasi mikroflora gastrointestinal harus terjaga.

Sejumlah besar mikroorganisme yang menghuni permukaan tubuh mamalia memiliki hubungan yang sangat berkaitan dengan sistem kekebalan tubuh. Meskipun banyak dari mikroba ini melaksanakan fungsi yang sangat penting untuk fisiologi inang, mereka tetap menimbulkan ancaman sebagai patogen bagi tubuh. Sistem kekebalan tubuh manusia memainkan peran penting dalam mempertahankan homeostasis dengan mikrobiota, sehingga memastikan bahwa hubungan mutualisme dengan inang dapat dipertahankan. Pada waktu yang bersamaan, mikrobiota dapat membentuk sistem kekebalan manusia. Oleh karena itu, paradigma baru mengemukakan bahwa sistem kekebalan tubuh telah berkembang untuk mengakomodasi kolonisasi dari mikrobiota simbiosis yang bertambah kompleks namun tetap mempertahankan kapasitas untuk melawan patogen. Bagaimana koloni bakteri dari usus dapat mempengaruhi perkembangan dan fungsi dari sistem imun menjadi pusat pembelajaran yang menarik (Hooper et al., 2012). Di sini, kami membahas prinsipprinsip yang mengatur hubungan interaksi antara mikrobiota usus dan sistem kekebalan tubuh inang, baik dalam kesehatan dan penyakit.

\section{Mikrobiota di Awal Perkembangan}

Collado et al. (2006) menyatakan

bahwa pencegahan $N C D s$ dapat dilakukan dengan memperhatikan mikrobioma sejak awal kehidupan. Sistem gastrointestinal bayi akan memberikan lingkungan baru bagi kolonisasi mikroba. Mikrobiota bayi yang dilahirkan dengan persalinan normal memiliki kemiripan dengan mikrobiota di vagina ibunya pada 20 menit awal kehidupan. Spesies mikrobiota yang ditemukan ialah Lactobacillus sp. dan
Prevotella $s p$. Terdapat perbedaan antara spesies mikrobiota bayi yang dilahirkan dengan persalinan normal dan operasi sesar. Mikrobiota pada bayi yang dilahirkan secara sesar yaitu Clostridium sp., Staphylococcus sp., Propionobacteriu sp., dan Corynebacterium sp. (Gritz, 2015). Mikrobioma di saluran gastrointestinal bayi yang baru lahir akan serupa dengan mikrobioma orang dewasa selama tahun pertama kehidupannya. Seiring dengan pertambahan usia akan terjadi perubahan mikrobioma karena dipengaruhi oleh ASI, demam, pengenalan terhadap makanan pendamping ASI, dan penggunaan antibiotik (Ursell et al., 2012).

Terdapat perbedaan jenis mikroba pada bayi yang mendapatkan ASI dengan yang mendapatkan susu formula. Perkembangan pada periode perinatal merupakan masa yang penting karena terjadi modifikasi yang mempengaruhi sistem imun dan penyakit yang berhubungan dengan inflamasi. Perkembangan mikrobioma diawali dengan transmisi secara vertikal dari mikrobiota maternal. Kolonisasi mikrobioma di mukosa sistem pencernaan, sistem pernapasan, saluran urogenital, dan kulit dipengaruhi oleh waktu pajanan dengan mikrobiota maternal. Lingkungan di dalam uterus bersifat steril, sehingga tidak terjadi kolonisasi mikroba tetapi, kolonisasi mikroba dapat terjadi sebelum persalinan. Kolonisasi mikroba terjadi karena telah terpajannya janin dengan plasenta dan meconium (Gritz dan Bhadhari, 2015).

Di plasenta terdapat berbagai mikrobiota seperti Firnicutes, Tenericutes, Proteobacteria, Bacteroidetes, dan Fusobacteriaphyla. Mikrobiota tersebut sama dengan mikrobiota yang terdapat di mulut manusia. Pada minggu pertama awal kehidupan, kolonisasi mikrobiota di usus dipenuhi oleh Actinobacteria, Proteobacteria, Bacteroidetes, dan Firmicutes. Mikroba yang terdapat di meconium sama dengan mikroba di cairan amnion karena ketika sistem saraf janin mulai berkembang, janin dapat menelan cairan amnion. Oleh karena itu, lingkungan usus janin dapat menjadi tempat kolonisasi mikroba sehingga tidak steril (Sudarmono, 2016). 


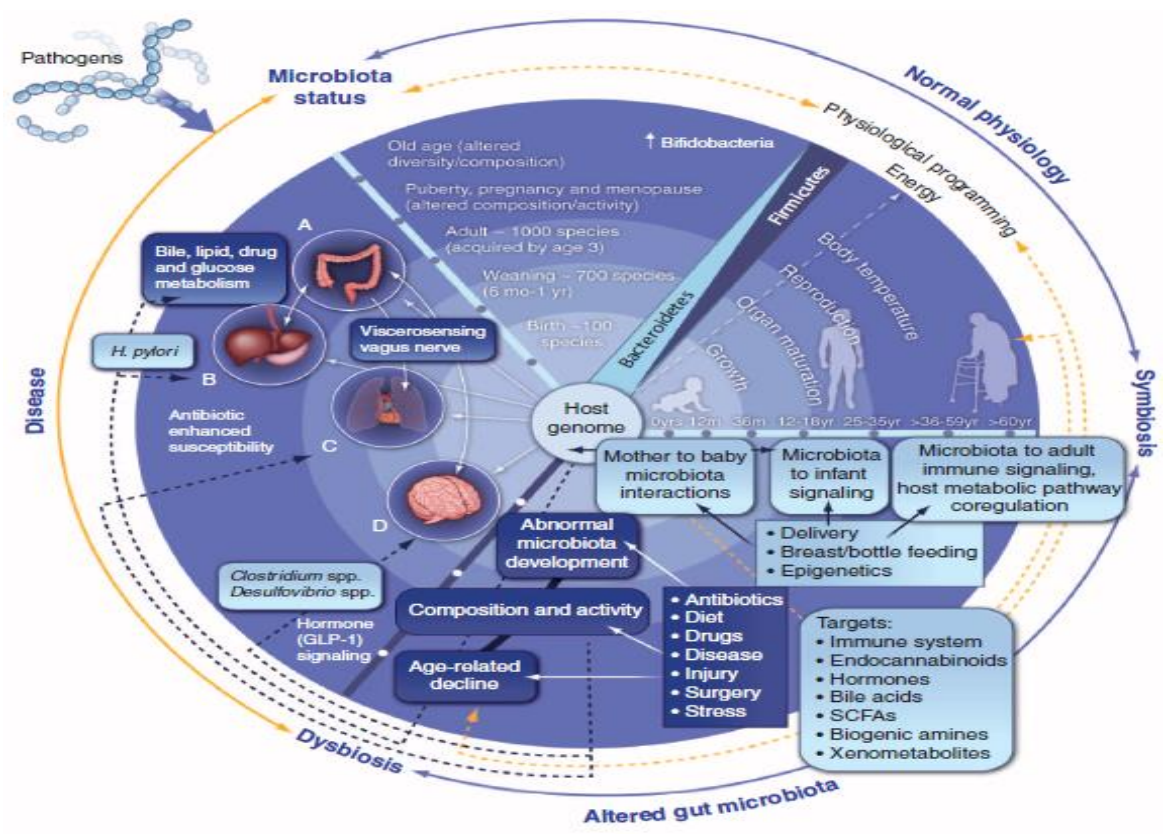

Gambar 1. Mikrobiota usus dalam perkembangan dan penyakit. Pengaruh dari mikrobiota usus terhadap kesehatan manusia adalah berkelanjutan dari lahir hingga dewasa. Faktor lingkungan, faktor nutrisi, dan faktor telah dilibatkan dalam perkembangan untuk simbiosis dari kesehatan usus dan mikrobiota (Nicholson et al., 2012).

Menariknya, setiap perubahan makanan diikuti dengan perubahan pada mikrobiota pencernaan dan peningkatan ekspresi gen. Sebagai contoh, pada bayi yang mulai mengenal makanan dewasa, ekspresi gen mikrobioma terkait biosintesis vitamin dan pencernaan polisakarida meningkat. Dengan demikian, interaksi antara mikrobiota manusia dan lingkungan menjadi amat dinamis (Ursell et al., 2012).

\section{Peran Mikrobiota}

Bakteri yang hidup di dalam tubuh manusia merupakan koloni bakteri yang bermanfaat. Peran mikrobioma adalah membantu mencerna makanan, mengatur sistem imun, dan perlindungan terhadap bakteri pathogen. Mikrobioma berada di kulit, sistem gastrointestinal, saluran napas, dan saluran urogenital; saluran yang berhubungan langsung dengan dunia luar sehingga dapat terpajan langsung oleh faktor eksternal, seperti makanan, udara, dan obatobatan. Setiap individu memiliki respons berbeda pada metabolisme mikrobioma (Dietert, 2015).

Tanpa mikrobiota usus, tubuh manusia tidak akan mampu memanfaatkan beberapa karbohidrat yang belum tercerna untuk mengkonsumsi, karena beberapa jenis mikrobiota usus memiliki enzim dimana selsel manusia tidak mampu untuk memecahkannya khususnya polisakarida (Clarke et al., 2014). Bakteri mengubah karbohidrat dengan cara berfermentasi menjadi asam lemak rantai pendek (SCFAs) disebut fermentasi sakarolitik. Produknya meliputi asam asetat, asam propionat, dan asam butirat. Produkini dapat digunakan oleh sel inang, menyediakan sumber utama energi dan nutrisi bagi manusia, serta membantu tubuh menyerap mineral penting seperti kalsium, magnesium, dan zat besi (Gibson dan Glenn, 2004). Gas dan asam organik (seperti asam laktat) juga diproduksi oleh fermentasi sakarolitik (Guarner dan Malagelada, 2003). Asam asetat digunakan oleh otot, asam propionat membantu hati menghasilkan ATP, dan asam butirat memberikan energi untuk sel usus dan dapat mencegah kanker (Beaugerie et al., 2004). Bukti lain yang menunjukkan bahwa bakteri meningkatkan penyerapan dan penyimpanan lipid kemudian memfasilitasi tubuh untuk menyerap vitamin 
yang diperlukan seperti vitamin K (Sears, 2005).

Mikrobiota juga mensintesis vitamin (seperti biotin dan folat) dan membantu penyerapan unsur makanan (termasuk magnesium, kalsium dan zat besi) (O'Hara, 2006). Archae seperti Methanobrevibacter smithii terlibat dalam pemindahan produk akhir fermentasi bakteri seperti hidrogen (Sherwood et al., 2013).

Disfungsi mikrobioma dapat menimbulkan penyakit seperti penyakit autoimun (diabetes, rheumatoid arthritis, distrofi otot, multiple sclerosis, dan fibromialgia). Akumulasi mikroba penyebab penyakit akanmenyebabkan perubahan aktivitas gen dan metabolik. Akibat perubahan tersebut adalah abnormalitas sistem imun, sehingga akanmenyerang zat dan jaringan yang pada keadaan normal terdapat di dalam tubuh (Ursell et al., 2012).

\section{Penghalang Usus}

Pada dasarnya, interaksi spasial antara mikrobiota dan sistem kekebalan usus dapat dibagi menjadi tiga lapisan. Lapisan pertama, menghadap ke lumen usus, terdiri terutama oleh lendir dan dapat dibagi menjadi dua sub-lapisan: sublapisan luar, kurang padat, sangat dijajah oleh mikrobiota, sedangkan lapisan mukosa bagian dalam terdiri dari konsentrasi tinggi antimikroba bakterisida peptida (AMP) dan sekretori $\operatorname{Ig} \mathrm{A}$ (SIgA) khusus untuk mikroorganisme yang menguntungkan. Lapisan kedua terdiri dari lapisan tunggal dari sel epitel usus (IECs) yang berhubungan dengan lamina propria (LP) di permukaan basolateral dan dengan lapisan mukosa pada permukaan apikal. IEC yang disusun oleh beberapa jenis sel, seperti sel-sel goblet yang menghasilkan musin (membentuk lendir); enterosit serap dan sel enteroendokrin, baik memproduksi cholecystokinin dan ghrelin (yang mengatur nafsu makan);sel Paneth, produsen terkemuka AMP; dan sel M, yang terlibat dalam menangkap antigen untuk menyajikan mereka untuk sistem kekebalan tubuh (Collins et al., 2012; Johansson, 2014).

IECs memiliki peran yang sangat penting dalam memisahkan organ-organ tubuh dari lingkungan luar melalui pembentukan persimpangan ketat dan sekresi lendir dan AMP (seperti defensin, lysozymes, cathelicidins, fosfolipase-A2, dan C-jenis lektin) (Goto dan Ivanov, 2013). Selanjutnya, ECs mengekspresikan reseptor pengenalan pola (PRRS), yang meliputi reseptor Toll-like (TLR), reseptor Nod-seperti (NLRs), dan Rig-I sseperti reseptor (Lavelle et al., 2010). Sebuah jenis sel yang sangat penting hadir dalam lapisan IECs adalah sel M. Sel-sel ini bekerja secara langsung dengan sistem kekebalan tubuh, sampling antigen dari lumen dan membawa mereka dengan cara searah untuk antigen sel presentasi lokal di bawah epitel (Goto dan Ivanov, 2013). Sel enteroendokrin juga bertindak dalam perlindungan penghalang usus dengan memproduksi enteroendokrin peptida glukagon-like peptide-2 (GLP-2), yang diatur oleh status gizi inang, seperti rantai pendek produksi asam lemak. Karakteristik utama dalam fungsi penghalang usus GLP-2 yang merangsang usus proliferasi sel epitel; meningkatkan ekspresi usus protein persimpangan ketat; dan mengatur sistem kekebalan tubuh bawaan dengan mengontrol ekspresi peptida antimikroba yang diproduksi oleh sel Paneth (Cani et al., 2013).

Lapisan ketiga, di bawah IECs, dibentuk oleh lamina propria dan mesenterium. Unsur-unsur sistem kekebalan tubuh gut-associated lymphoid tissue (GALT) berada dalam lapisan ini. Di lamina propria, terisolasi limfoid folikel dewasa (ILFs), yang terbentuk dari patch crypt (prenatal) dan patch Peyer (PPs), dapat ditemukan. Microbe-associated molecular patterns (MAMPs) yang berasal dari koloni bakteri dirasakan oleh PRRS di IECs atau sel dendritik (DC) yang merekrut dan mengaktifkan $\mathrm{T}$ dan sel $\mathrm{B}$ di ILFs.PP, di bawah IECs, menerima antigen melalui selsel $M$ dan meneruskannya ke DC, yang berinteraksi dengan sel $\mathrm{T}$ dan $\mathrm{B}$. Dalam PP dan ILFs ada beberapa sel plasma yang biasanya memproduksi dan melepaskan IgA (Kamada et al., 2013). 


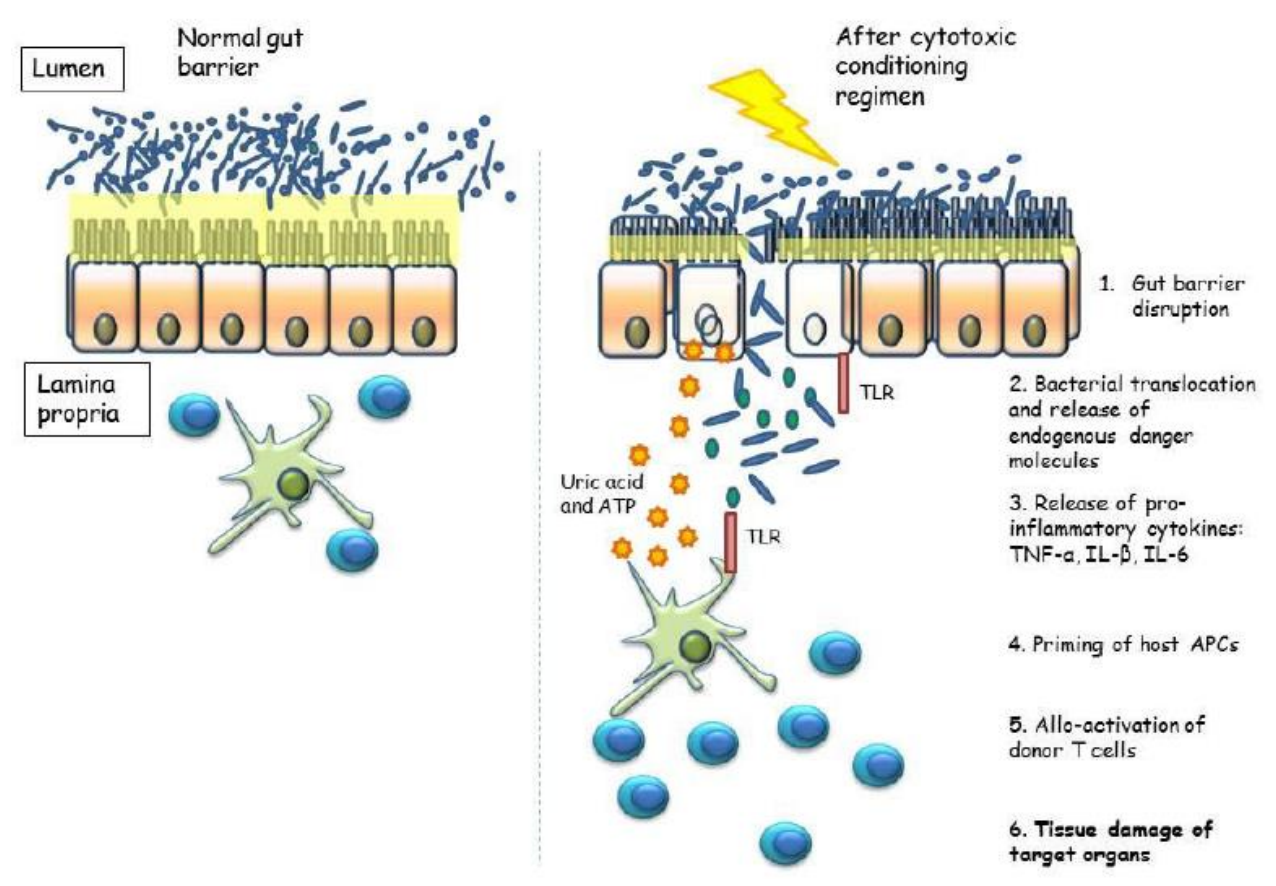

Gambar 2. Penghalang usus dan perubahannya selama pathogenesis oleh GVHD (Heidegger et al., 2014)

\section{Interaksi Mikrobiota dan Sistem Imun Usus}

Interaksi fungsional antara mikrobiota dan sistem kekebalan usus dimulai dengan bakteri komensal yang mempromosikan lingkungan anti-inflamasi (Gambar 3). Dalam konteks simbiosis, MAMPs terus merangsang IECs untuk mengeluarkan regenerasi $\gamma$ REGIII ke lumen, thymus stroma lymphopoietin (TSLP), IL-33, IL-25, dan pertumbuhan tumor factor $\beta(T G F-\beta)$ di bawah epitel. Mediator imunologi mendorong perkembangan makrofag tolerogenic dan DC tolerogenic (Maynard et al., 2012). DC tolerogenic menghasilkan TGF- $\beta$ dan asam retinoat (RA) yang merangsang perkembangan sel-sel peraturan T. Dengan demikian, melalui sel-sel Treg (yang menggunakan mekanisme beragam regulasi), makrofag (yang menghasilkan IL10), dan DC tolerogenik, sistem kekebalan usus mampu membangun dan memelihara lingkungan anti-inflamasi. Selain peran regulasi penting dari TGF- $\beta$, sitokin ini dikaitkan dengan zat epitel yang diturunkan lainnya (seperti sel B activating factor (BAFF) dan proliferasi-inducing ligand (Aprill)), dalam rangka mendorong pengembangan IgA- memproduksi sel (sel plasma) (Fagarasan et al.,
20102.Immunoglobulin ini mampu mencegah pengikatan bakteri komensal pada epitel inang dan dengan demikian terlibat dalam pembentukan usus mikrobiota (Macpherson et al., 2012).

Dalam konteks dysbiosis, kehadiran patogen dapat mengganggu lingkungan antiinflamasi diatur ini. Ketika patogen enterik mengatasi bakteri komensal, ketidakseimbangan antara komensal dan bakteri patogen menyebabkan pembebasan yang signifikan dari MAMPs. Peningkatan MAMPs ini dapat menginduksi IECs, DC diaktifkan, dan makrofag untuk mengeluarkan sitokin inflamasi seperti IL$1 \beta$, IL-6, IL-12, dan IL-23.Sitokin ini merangsang perkembangan efektor $\mathrm{CD} 4{ }^{+} \mathrm{T}$ helper 1 (TH1) sel dan sel TH17 (yang memproduksi IL-17A, IL-17F, dan IL-22) yang mengakibatkan peradangan kronis (Maynard et al., 2012). Dalam konteks ini, IL-22 sitokin memiliki peran penting. Molekul ini, diproduksi oleh sel TH17 dan oleh sel kekebalan bawaan (seperti NK-sel dan sel $\gamma \delta \mathrm{T}$ ), bertindak pada sel-sel epitel usus dengan menginduksi ekspresi beberapa AMP sebagai $\gamma$ REGIII dan $\beta$ REGIII yang secara langsung mempengaruhi mikrobiota. Menariknya, sel proinflamasi diaktifkan tampaknya bekerja baik dalam simbiosis dan dysbiosis; Namun, 
dalam kasus simbiosis, sel-sel proinflamasi yang dikendalikan dengan mekanisme pengaturan (DC tolerogenic dan makrofag dan sel peraturan $\mathrm{T}$ ) dan berkontribusi dengan melepaskan IL-22, yang mempromosikan produksi $\gamma$ REGIII oleh IECs dan membantu untuk melindungi barrier epitel (Maynard et al., 2012).

Meskipun mekanisme yang dijelaskan di atas sudah diketahui dengan pastidengan didukung berbagai publikasi, banyak aspek dari hubungan mikroba dan sistem kekebalan tubuh yang masih harus dijelaskan. Selain itu, studi terbaru telah menambahkan bukti lebih lanjut yang menunjukkan bagaimana mikrobiota dan sistem kekebalan tubuh dapat berinteraksi untuk mempertahankan homeostasis.

\section{Bukti-bukti baru tentang Mikrobiota Usus dan Sistem Kekebalan}

Studi terbaru lainnya telah membahas interaksi antara mikrobiota usus dan sistem kekebalan tubuh. Interaksi ini mungkin terkait dengan menjaga keseimbangan antara mikrobiota usus dan sistem sumbu kekebalan tubuh, baik lokal dan sistemik.

Masahata et al. (2014) menunjukkan adanya hubungan antara sel-sel sekresi-IgA dan komposisi mikrobiota. Dalam penelitian ini, menafsirkan pentingnya hubungan usus buntu dengan jaringan limfoid di IgA dalam mensekresi generasi sel dari tikus yang bebas bakteri dan tikus yang diserang bakteri usus buntu. Penelitian ini menemukan penurunan sel $\operatorname{IgA}$ yang mensekresi di usus besar, serta penurunan tingkat IgA di feses. Bersamaan dengan itu, terlihat penurunan yang signifikan dalam jumlah spesies bakteri feses pada tikus yang terkena usus buntu. Namun menariknya, perbedaanperbedaan dari jumlah sel sekresi-IgA dan koloni bakteri menghilang setelah delapan minggu penjajahan. Normalisasi pada sel sekresi-IgA di kolon berkorelasi dengan peningkatan dan pembesaran jaringan limfoid usus. Dengan demikian, hasil ini menunjukkan bahwa sel-sel sekresi-IgA terlibat dalam pemeliharaan homeostasis mikroba dalam ususbesar dan berkontribusi untuk membentuk koloni mikroba normal.

Beberapa penelitian lain mencoba untuk mengidentifikasi metabolit dari mikrobiota dapat mempengaruhi sistem kekebalan tubuh dan menyebabkan homeostasis. Dalam konteks ini, Smith et al. (2013) menunjukkan bahwa tikus yang bebas bakteri memiliki penurunan yang signifikan pada konsentrasi tiga jenis yang paling melimpah dari asam lemak rantai pendek (SCFA: asam asetat, asam propionat, dan asam butirat) menunjukkan hubungan antara molekul-molekul dan kekebalan masalah yang dihadapi oleh jenis tikus. Untuk memperjelas pertanyaan ini, tikus bebas bakteri diobati dengan SCFA (individual atau dalam kombinasi) selama 3 minggu. Seperti yang diharapkan, tikus ini menunjukkan peningkatan frekuensi dan jumlah sel Treg kolon, yang tidak terjadi dengan TH1 atau TH17 sel. Perlakuan SCFA juga mampu menginduksi peningkatan FoxP3 dan $I L$-10 ekspresi gen dan IL-10 produksi, menunjukkan bahwa SCFA dapat menginduksi khusus ${ }^{+} \mathrm{IL}-10$ memproduksi sel Treg FoxP3. Selain itu, pengobatan SCFA mampu juga untuk mengurangi gejala $\mathrm{T}$ sel model-transfer kolitis. Secara kolektif, hasil ini menunjukkan bahwa SCFA memainkan peran penting dalam mempertahankan homeostasis melalui sel-sel Treg.

Perubahan fungsi penghalang gastrointestinal, yang disebabkan oleh perubahan diet, juga dapat mengembangkan endotoxemia (Pendyala et al., 2012). Selama dysbiosis, usus mikrobiota dapat menghasilkan tingkat tinggi endotoksin, dalam aliran darah menyebabkan induksi ringan dan berkesinambungan mediator proinflamasi, yang mengakibatkan peradangan sistemik ringan. Bagian inflamasi ini berkontribusi pada perkembangan banyak penyakit manusia, termasuk obesitas, diabetes tipe 2 , hati dan penyakit kardiovaskular, dan penyakit inflamasi usus. 


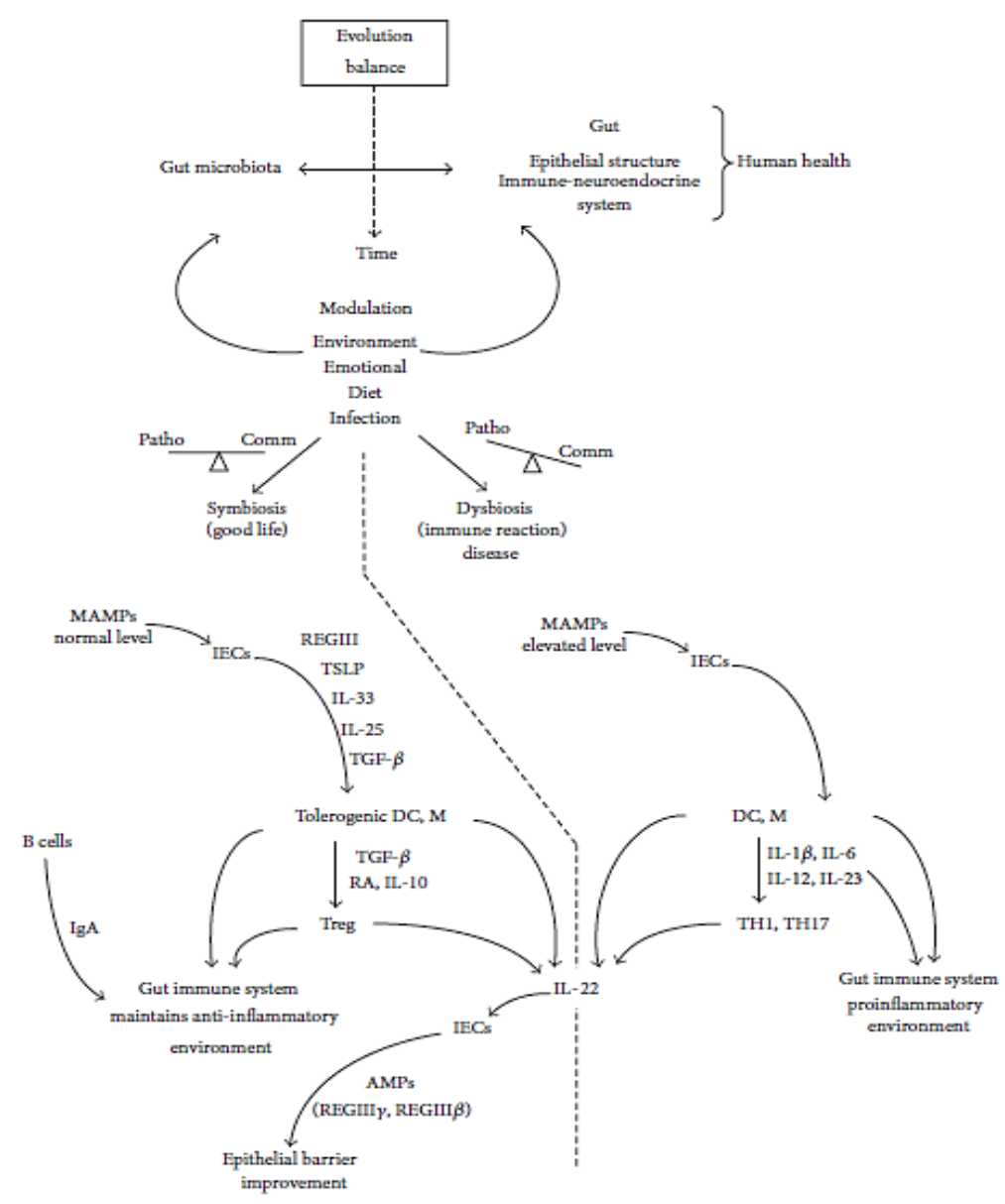

Gambar 3. Interaksi fungsional antara mikrobiota dan sistem kekebalan usus. Keseimbangan evolusi dipengaruhi oleh tekanan lingkungan (Maranduba et al., 2014)

\section{DAFTAR PUSTAKA}

Beaugerie, Laurent, Petit, Jean-Claude. 2004. Antibiotic-associated diarrhoea. Best Practice \& Research Clinical Gastroenterology 18 (2): 337-52.

Cani, P. D., Everard, A., dan Duparc, T. 2013. Gut microbiota, enteroendocrine functions and metabolism. Current Opinionin Pharmacology 13(6): 935-940.

Clarke G, Stilling RM, Kennedy PJ, Stanton C, Cryan JF and Dinan TG. 2014. Minireview: Gut microbiota: the neglected endocrine organ. Mol. Endocrinol. 28 (8): 1221-1238.

Collins, S. M., Surette, M., dan Bercik, P. 2012. The interplay between the intestinal microbiota and the brain. Nature Reviews Microbiology 10(11):735-742.
Collado, MC., Surono, IS., Meriluato, J., Salminen, S. 2006. Potencial probiotic characteristic of Lactobacillus and Enterococcuc strain isolated from traditional dadih fermented milk against pathogen intestinal colonization. J Food Protection 70(3): 700-705.

Dietert RR, Dietert JM. 2015. Review: the microbiome and sustainable healthcare. Healthcare. 3: 100-129.

Fagarasan, S., Kawamoto, S., Kanagawa, O dan Suzuki, K. 2010. Adaptiveimmune regulation in the gut: $\mathrm{T}$ cell-dependent and $\mathrm{T}$ cellindependent IgAsynthesis. Annual Review of Immunology 28(1): 243273.

Gibson, Glenn R. 2004. Fibre and effects on probiotics (the prebiotic concept). Clinical Nutrition Supplements 1(2): 25-31. 
Gritz EC, Bhandari V. 2015. The human neonatal gut microbiome: a brief review. Frontiers in Pediatrics 3:1-12.

Goto, Y. dan Ivanov, I. I. 2013. Intestinal epithelial cells as mediators of the commensal-host immune crosstalk. Immunology and Cell Biology 91(3): 204-214.

Guarner, F dan Malagelada, J. 2003. Gut flora in health and disease. The Lancet. 361 (9356): 512-519.

Heidegger, S., Van den Brink MR., Haas T., Poeck, H. 2015. The role of patternrecognition receptors in graft-versushost disease and graft-versusleukemia after allogeneic stem cell transplantation. Frontiers in immunology 5: 337.

Hooper, L.V., Littman, DR., Macpherson, A.J. 2012. Interactions between in microbiota and the immnune system. Science 336.

Johansson, M., Larsson, J. H., dan Hansson, G. 2011. The two mucus layers of colon are organized by the MUC2 mucin, whereas the outer layer is a legislator of host-microbial interacttions. Proceedings of the National Academy of Sciences USA 108(1): 4659-4665.

Kamada, N., Seo, S., Chen, G., dan N'ũ nez. G. 2013. Role of the gut microbiota in immunity and inflammatory disease. Nature Reviews Immunology 13(5): 321-335.

Macpherson, A.J., Geuking, M.B. dan McCoy, K.D. 2012. Homeland Security: IgA immunity at the frontiers of the body. Trends in Immunology 33(4): 160-166.

Maranduba, C.M.D.C., Castro, S.B.R.D., Souza, G.T.D., Rossato, C., Guia, F.C.D., Valente, M.A.S., Rottore, J.V.P., Maranduba, C.P., Souza, C.M.D., Carmo, A.M.R.D., Macedo, G.C. dan Silva, F.D.S. 2015. Intestinal microbiota as modulators of the immune system and neuroimmune system: impact on the host health and homeostasis. Hindawi Publishing Corporation. Journal of Immunology research 2015.
Masahata, K., Umemoto, E., Kayama, H. 2014. Generation of colonic IgAsecreting cells in the caecal patch. Nature Communications 5: 3704.

Maynard, C. L., Elson, C. O., Hatton, R. D., and Weaver., C. T. 2012. Reciprocal interactions of the intestinal microbiota. Nature 489 : 231-241.

Nicholson, J.K., Holmes, Elaine., Kinross, James., Burcelin, Remy., Gibson, Glenn., Jia, Wei., Pettersson, Sven. 2012. Host-Gut Microbiota Metabolic Interactions. Science 336: 1262.

O'Hara, Ann M; Shanahan, Fergus. 2006. The gut flora as a forgotten organ. EMBO Reports 7(7): 688-693.

Pendyala, S., Walker, J. M. dan Holt, P. R. 2012. A high-fat diet is associated with endotoxemia that originates from the gut. Gastroenterology 142(5):1100-1101.

Prakash, Satya., Rodes, Laetitia., Charley, MC., Duchesneau, CT. Gut microbiota: next frontier in understanding human health and development of biotherapeutics. Biologics: Targets and Therapy 5: 7186.

Rolfe RD. 2000. The Role of Probiotic Cultures in the Control of Gastrointestinal Health. J. of Nutr. 130: 396-402.

Sears, Cynthia L. 2005. A dynamic partnership: Celebrating our gut flora. Anaerobe. 11 (5): 247-251.

Sudarmono PP. 2016. Mikrobioma: Pemahaman Baru tentang Peran Mikroorganisme dalam Kehidupan Manusia. Mikrobioma, 4(2).

Ursell LK, Metcalf JL, Parfrey LW, Knight R. 2012. Defining the human microbiome. Nutr Rev. 70: 38-44. 